\title{
Intracrystalline microstructures in alkali feldspars from fluid-deficient felsic granulites \\ A mineral chemical and TEM study
}

\author{
Journal Article \\ Author(s): \\ Tajčmanová, Lucie; Abart, Rainer; Wirth, Richard; Habler, Gerlinde; Rhede, Dieter \\ Publication date: \\ 2012-10 \\ Permanent link: \\ https://doi.org/10.3929/ethz-b-000058113
}

Rights / license:

In Copyright - Non-Commercial Use Permitted

Originally published in:

Contributions to Mineralogy and Petrology 164(4), https://doi.org/10.1007/s00410-012-0772-2 


\title{
Intracrystalline microstructures in alkali feldspars from fluid-deficient felsic granulites: a mineral chemical and TEM study
}

\author{
Lucie Tajčmanová $\cdot$ Rainer Abart . \\ Richard Wirth · Gerlinde Habler · Dieter Rhede
}

Received: 7 November 2011/ Accepted: 16 May 2012/Published online: 1 June 2012

(C) Springer-Verlag 2012

\begin{abstract}
Samples of essentially "dry" high-pressure felsic granulites from the Bohemian Massif (Variscan belt of Central Europe) contain up to 2-mm-large perthitic alkali feldspars with several generations of plagioclase precipitates in an orthoclase-rich host. The first generation takes the form of lenses homogeneous in size, whereas the size of a second generation of very thin albite-rich precipitates is more variable with comparatively high aspect ratios. In the vicinity of large kyanite, garnet or quartz inclusions, the first generation of plagioclase precipitates is significantly less abundant, the microstructure is coarser than in the remainder of the perthitic grain and the host is a tweed orthoclase. The first generation of precipitates formed at around $850{ }^{\circ} \mathrm{C}$ during the high-pressure stage (16-18 kbar) of metamorphism. Primary exsolution was followed by primary coarsening of the plagioclase precipitates, which still took place at high temperatures $\left(850-700^{\circ} \mathrm{C}\right)$. The coarsening was pronounced due to the
\end{abstract}

Communicated by T. L. Grove.

L. Tajčmanová $(\bowtie)$

Department of Earth Sciences,

Swiss Federal Institute of Technology,

8092 Zurich, Switzerland

e-mail: lucataj@gmail.com

L. Tajčmanová

Czech Geological Survey, Klárov 3, 11821 Prague 1,

Czech Republic

R. Abart - G. Habler

Department of Lithospheric Research, University of Vienna,

Althanstrasse 14, 1090 Wien, Austria

R. Wirth · D. Rhede

Deutsches GeoForschungsZentrum, Telegrafenberg,

14473 Potsdam, Germany access of fluids in the outer portions of the perthitic alkali feldspar and in more internal regions around large inclusions. The second generation of albite-rich precipitates was formed at around $570{ }^{\circ} \mathrm{C}$. TEM investigations revealed that the interfaces between the second-generation plagioclase lamellae and the orthoclase-rich host are coherent or semicoherent. During late evolutionary stages of the perthite, albite linings were formed at phase boundaries, and the perthitic microstructure was partially replaced by irregularly shaped precipitates of pure albite with incoherent interfaces. The albitization occurred below $400{ }^{\circ} \mathrm{C}$ and was linked to fluid infiltration in the course of deuteric alteration. Based on size-distribution analysis, it is inferred that the precipitates of the first generation were most probably formed by spinodal decomposition, whereas the precipitates of the second generation rather were formed by nucleation and growth.

Keywords Bohemian Massif - High-pressure granulites · Perthite - Nucleation and growth - Size distribution . Spinodal decomposition

\section{Introduction}

Perthite is a typical microstructure in alkali feldspar that is generated by exsolution of a more albite-rich phase from alkali feldspar or ternary feldspar of an intermediate composition producing at the same time a more orthoclaserich host. Perthitic microstructures have been described from many slowly cooled granitic rocks (Parsons and Brown 1983; Brown and Parsons 1984a, b, 1988; Parsons et al. 2005; Fitz Gerald et al. 2006; Hartmann et al. 2008; Abart et al. 2009a, b). Mechanisms controlling microstructure evolution in perthites from slowly cooled rocks 
are, however, only poorly known (Yund 1984). The initial phase separation may occur by a combined nucleation/ growth mechanism and/or by spinodal decomposition (Cahn 1968; Owen and McConnell 1974; Brown and Parsons 1984a; Yund 1984; Abart et al. 2009a, b). Exsolution by spinodal decomposition is typical of an intermediate compositional range, whereas for albite-rich or orthoclaserich alkali feldspar exsolution more likely occurs by a nucleation/growth mechanism. Typically, if exsolution takes place under fluid-deficient conditions, the precipitate-host interfaces are coherent initially, and the shape as well as the shape preferred orientation of a precipitate are crystallographically controlled producing a highly organized microstructure. Irrespective of whether exsolution occurs by nucleation/growth or by spinodal decomposition, the initial phase separation stage is followed by capillary force-driven coarsening (Balluffi et al. 2005). Coarsening and accompanying recrystallization may lead to partial or complete loss of coherency and formation of complex microstructures (Parsons and Brown 1983; Brown and Parsons 1984a, 1988; Parsons et al. 2005; Fitz Gerald et al. 2006; Abart et al. 2009a, b). Finally, the primary exsolution microstructure can be completely obliterated during fluidmediated alteration and recrystallization (Parsons and Lee 2009; Parsons et al. 2010).

If preserved in its original state, the size distribution (SD) of the precipitates may help to identify the mechanisms underlying exsolution under fluid-deficient conditions. The different kinetic pathways, in particular, nucleation/growth and spinodal decomposition produce distinct SD's (by Cahn and Hilliard 1958, 1959; Nauman and He 2001; Abart et al. 2009a). Such a diagnostic SD may be modified during subsequent coarsening and ultimately a steady-state distribution may be attained during prolonged coarsening, where the particular shape of the steady-state SD's depends on whether the coarsening is diffusion- or interface reaction controlled (Lifshitz and Slyozov 1961; Wagner 1961). The SD may thus be diagnostic for the exsolution mechanism and for the extent and nature of subsequent coarsening (e.g. Weinbruch et al. 2003, 2006). With respect to perthite formation, it is expected that the SD is diagnostic for the kinetic pathway underlying exsolution, only if it is preserved from an early stage of microstructure evolution. If capillary force-driven ripening becomes substantial, the microstructure evolves towards a steady-state $\mathrm{SD}$, and the "memory" of the exsolution mechanism may be partially or entirely lost.

In this contribution, we apply electron beam microanalytical techniques to document several stages of microstructure evolution of coarse-grained perthite during decompression and subsequent cooling of felsic highpressure granulites from the Moldanubian domain (Bohemian Massif). Thereby, we distinguish between two early generations of exsolution features, which show a high degree of spatial organization and later generations, which take a form of irregularly shaped replacement albite supposedly related to deuteric alteration. Similar two-stage microstructure seems to be common in most of the hightemperature alkali feldspars and was already extensively described (e.g. Evangelakakis et al. 1993; Parsons et al. 2005; Hartmann et al. 2008; Abart et al. 2009a, b). However, the heterogeneous distribution of coarsening of an early generation, which is another common feature in granulites, is still not entirely explained. Here, we therefore focus on the spatial distribution of the heterogeneous coarsening in detail and bring new interpretations on the development of such a microstructure. Moreover, sizedistribution analysis was done for the first two generations of plagioclase precipitates to test whether some memory of the original exsolution process has been retained.

\section{Analytical techniques}

Microprobe analyses were carried out on a JEOL JXA8200 Superprobe equipped with 5 WDS detectors at the Free University of Berlin. An acceleration voltage of $15 \mathrm{kV}$ and a beam current of $20 \mathrm{nA}$ were applied. The probe diameter was set to $5-10 \mu \mathrm{m}$ for point analyses in all feldspar grains to minimize the loss of Na. Natural and synthetic mineral standards were used for calibration, and ZAF correction was applied. Integrated compositions were estimated from averaging automated point analyses with the $10-\mu \mathrm{m}$ steps from an area of $100 \times 100 \mu \mathrm{m}$.

High spatial resolution element maps and compositional profiles were carried out on a JEOL thermal field emissiontype electron-probe JXA-8500F (HYPERPROBE) at the GFZ German Research Centre for Geosciences, Helmholtz Centre Potsdam. The element distribution maps were produced in WDS mode with an acceleration voltage of $6 \mathrm{kV}$, a beam current of $10 \mathrm{nA}$, stage scanning mode and dwell times between 300 and $500 \mathrm{~ms}$ per pixel. The analytical conditions for chemical composition profiles across the lamellae included the acceleration voltage of $6 \mathrm{kV}$, a beam current of 3-5 nA and a focused electron beam with a diameter of about $30 \mathrm{~nm}$. Peak counting times were 8-20 s. Additional high-resolution images were produced on a FEI Quanta 3D FEG FIB-SEM (Scanning Electron Microscope) instrument at the Free University of Berlin (currently at GFZ Potsdam). Representative microprobe analyses of feldspars are listed in Table 1. Mineral abbreviations follow Kretz (1983) except for ternary feldspar (Fsp).

The internal microstructure and crystal orientation of the perthite was determined via electron backscatter diffraction (EBSD) and imaged using a standard forward scatter electron detector (FSED). EBSD analyses (Randle 1992; 
Table 1 Representative electron microprobe analyses of feldspars

\begin{tabular}{|c|c|c|c|c|c|c|}
\hline & \multicolumn{2}{|c|}{ Primary exsolutions } & \multicolumn{2}{|c|}{ Integrated composition } & \multicolumn{2}{|c|}{ Rock matrix } \\
\hline & Homogeneous & Coarsened & Ternary & Binary & Kfs & $\mathrm{Pl}$ \\
\hline \multicolumn{7}{|l|}{ Wt $\%$} \\
\hline $\mathrm{SiO}_{2}$ & 66.64 & 64.10 & 66.12 & 66.27 & 64.55 & 64.02 \\
\hline $\mathrm{Al}_{2} \mathrm{O}_{3}$ & 22.52 & 22.39 & 19.47 & 18.62 & 18.29 & 22.62 \\
\hline $\mathrm{CaO}$ & 4.20 & 3.95 & 1.04 & - & 0.05 & 4.23 \\
\hline $\mathrm{Na}_{2} \mathrm{O}$ & 6.58 & 8.38 & 4.13 & 2.20 & 0.66 & 9.02 \\
\hline $\mathrm{K}_{2} \mathrm{O}$ & 0.28 & 0.26 & 10.35 & 13.80 & 15.87 & 0.15 \\
\hline Total & 100.2 & 99.1 & 101.1 & 101.2 & 99.4 & 100.0 \\
\hline XAn & 0.26 & 0.20 & 0.05 & 0.00 & 0.00 & 0.20 \\
\hline $\mathrm{XAb}$ & 0.73 & 0.79 & 0.36 & 0.19 & 0.06 & 0.79 \\
\hline XOr & 0.01 & 0.01 & 0.59 & 0.81 & 0.94 & 0.01 \\
\hline
\end{tabular}

Prior et al. 1999; Randle and Engler 2000) were carried out using an EDAX-TSL DigiView EBSD detector attached to a Quanta 3D FEG FIB-SEM dual-beam instrument installed at the Free University of Berlin (currently at the GFZ Potsdam). The EBSD analyses were carried out via automatic beam mapping of individual images using the following setting: $20 \mathrm{keV}$ beam accelerating voltage; $23 \mathrm{nA}$ beam current; $10 \mathrm{~mm}$ working distance; $0.3-\mu \mathrm{m}$ step size and a tilt angle of $70^{\circ}$.

Ultrathin foils with dimensions of $15 \times 10 \times 0.1 \mu \mathrm{m}$ and serial sections from the host perthitic feldspar were prepared via sputtering by $\mathrm{Ga}$ ions using the focused ion beam system (FIB) on a FEI Quanta 3D FEG instrument at the University of Vienna (Austria) and at the GFZ Potsdam based on the procedures described by Wirth (2004, 2009). An acceleration voltage of $30 \mathrm{kV}$ was used throughout site-specific sputtering. For TEM foil preparation, beam currents of 65,15 and $3 \mathrm{nA}$ have been used during roughsputtering steps. After in situ lift-out using an Omniprobe $^{\mathrm{TM}} 100.7$ micromanipulator and Pt-deposition for mounting the TEM foil on a $\mathrm{Cu}$-grid, final thinning was performed at successively lower ion beam currents at $500 \mathrm{pA}, 100 \mathrm{pA}$ and finally $30 \mathrm{pA}$. Serial sections have been produced by automated alternating FIB sputtering and $\mathrm{EB}$ imaging using the $\mathrm{FEI}^{\mathrm{TM}}$ AutoSlice and View ${ }^{\mathrm{TM}}$ software. An ion beam accelerating voltage of $30 \mathrm{kV}$ and a beam current of $3 \mathrm{nA}$ have been used for the removal of $0.1-\mu m$-thick slices. After each cut, an image was taken using the electron beam and a solid-state BSE detector.

Transmission electron microscopy was carried out with a FEI-Tecnai F20-X-Twin TEM at the GFZ Potsdam. The instrument was operated at an accelerating voltage of $200 \mathrm{kV}$ with a field emission gun (FEG) as electron source. This TEM is equipped with a Gatan Tridiem GIF imaging filter. All TEM images presented here are energy-filtered images applying a $10-\mathrm{eV}$ window to the zero-loss peak. EEL spectra were acquired in diffraction mode with a camera length $770 \mathrm{~mm}$ and an acquisition time of $1 \mathrm{~s}$. The collection angle was $10 \mathrm{mrad}$. Dispersion was $0.1 \mathrm{eV} /$ channel. The GiF entrance aperture diameter was $2 \mathrm{~mm}$. For data evaluation, the Digital Micrograph software package was used. EDX analyses were done with an EDAX X-ray detector equipped with an ultrathin window. The TIA software package was used for data evaluation. EDX spectra were usually acquired in scanning transmission mode (STEM), scanning the electron beam in a preselected window thus minimizing mass loss during the acquisition of the spectra. The TEM is equipped with a Fishione high-angle annular dark field detector.

\section{Petrographic description of the Blanský les granulite}

The studied granulites are typical felsic granulites described from the southern part of the Moldanubian domain (sensu Suess 1912; Fig. 1) that is considered as the Variscan orogenic root domain of the Bohemian Massif (Schulmann et al. 2005, 2008). These rocks are characterized by a Grt-Ky/Sil \pm Bt-Pl-Kfs-Qtz mineral assemblage, and the samples from Blanský les massif (Fig. 1b) offer exceptionally well-preserved microstructures showing the complete granulite facies structural evolution (Franěk et al. 2006, 2011). The oldest fabric is represented by large grains of perthitic feldspar with inclusions of quartz, garnet and kyanite, more rarely biotite and accessory rutile, zircon and apatite reflecting peak $P-T$ conditions of $16-18 \mathrm{kbar}$ and $850-900{ }^{\circ} \mathrm{C}$ (Franěk et al. 2011; Tajčmanová et al. 2011). The garnet and kyanite inclusions document that these feldspars are relics of the high-pressure (HP) metamorphic event rather than magmatic relics (Tajčmanová et al. 2011). The works of Franěk et al. (2011) and Tajčmanová et al. (2011) document the coexistence of two feldspars, a K-rich ternary feldspar and plagioclase, at peak conditions. Low-pressure re-equilibration is characterized by corona structures around garnet and by plagioclase-spinel symplectites associated with the 


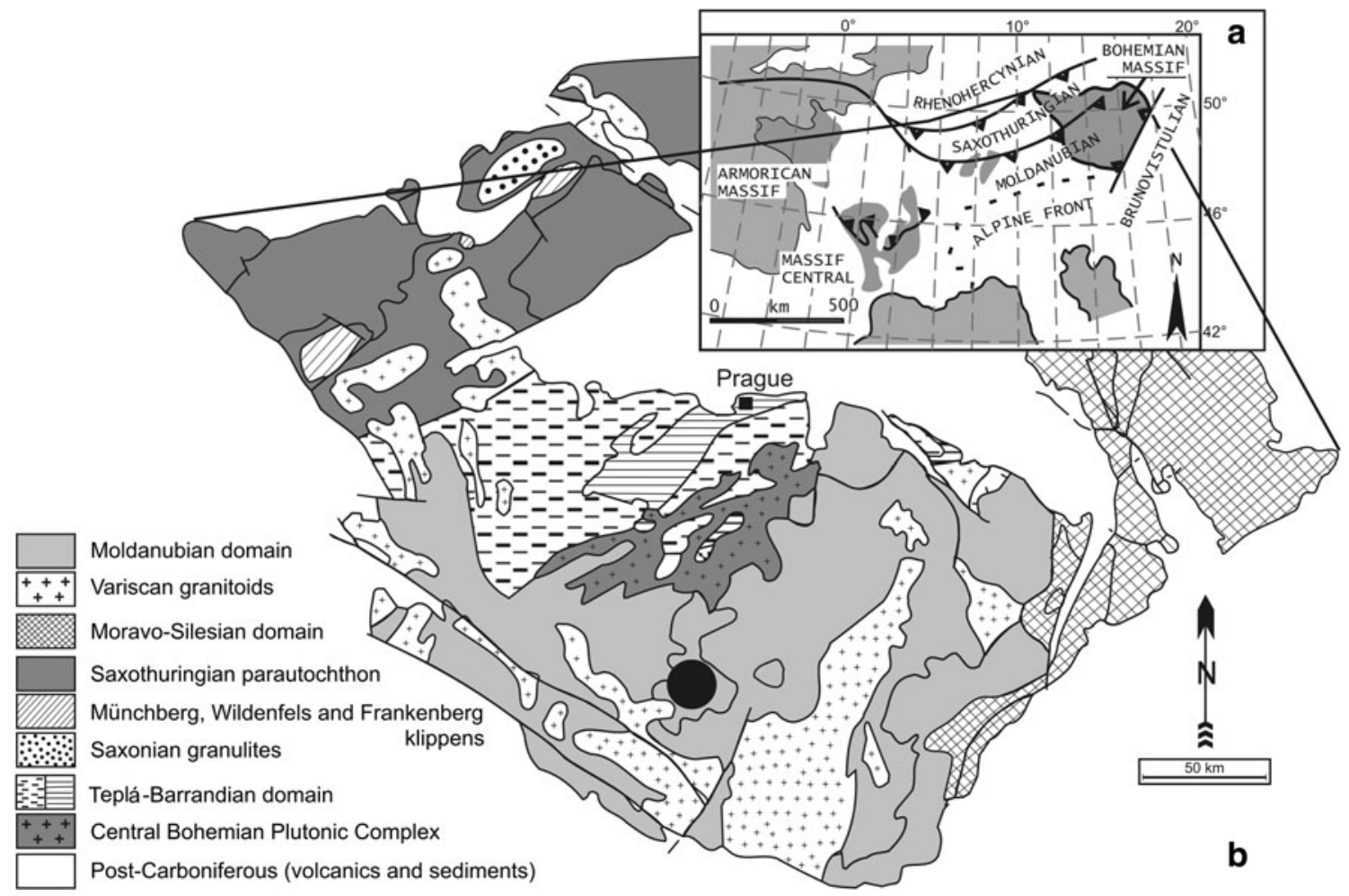

Fig. 1 a Location of the study area in the European Variscides b Geological map of the Bohemian Massif. The black circle represents the study area

formation of decompression plagioclase rims around kyanite crystals (Štípská et al. 2010; Tajčmanová et al. 2011).

\section{Alkali feldspar microstructures}

Samples of the felsic granulites contain large grains of perthitic feldspars with large inclusions of quartz, kyanite, biotite and garnets. Perthitic grains (up to $2 \mathrm{~mm}$ ) are surrounded by recrystallized feldspars (Fig. 2a) and quartz. The large alkali feldspars contain several generations of albite-rich plagioclase precipitates. The predominant oldest precipitate generation typically forms lenses with strong shape preferred orientation (Fig. 2b). The crystallographic orientation of orthoclase-rich host and plagioclase precipitate determined via EBSD is identical. The second generation of precipitates is represented by albite-rich films or lamellae (Fig. 2c). Finally, a late dispersed exsolution feature in the shape of short and narrow lamellae (tails) oriented slightly oblique to the main direction of primary exsolution lamellae (Fig. 2d) was observed. Those portions of the perthitic grains, where the first generation of exsolution lamellae prevails, will henceforth be referred to as the "homogeneous region" (Fig. 2b). In the immediate vicinity of large inclusions within the perthitic grains and in their outermost portions, the precipitates of the first generation are substantially less abundant and coarser grained than in the homogeneous region of the perthitic feldspar, and in addition, irregularly shaped albite-rich precipitates with significant associated porosity occur. These are henceforth referred to as the "coarsened regions" (Fig. 2c, e). The contacts between the orthoclaserich host and the plagioclase precipitates of the first generation and the contact between the orthoclase-rich host and large kyanite, quartz and garnet inclusions are coated with a thin rim of albite (Fig. 2c, d). In some regions of the large perthitic feldspars, irregularly shaped blebs of pure albite associated with high microporosity were observed (Fig. 2f).

Size distribution of exsolution lamellae

The first generation of albite-rich plagioclase precipitates takes the form of lenses with average longest axes of $30 \mu \mathrm{m}$ and average aspect ratio of 8.5. The size of the second generation of albite-rich precipitates is more variable. It takes the form of very thin $(<1 \mu \mathrm{m}$ thick) up to $10 \mu \mathrm{m}$ long lamellae, that is, with comparatively high aspect ratios (several hundreds). Both types of precipitate show strong shape preferred orientation along the Murchison plane (-601). In the vicinity of large kyanite, garnet or quartz inclusions, the primary exsolution lamellae 
Fig. 2 Back-scattered electron (BSE) images of a a large perthitic grain, b primary exsolution lamellae, $\mathbf{c}$ coarsened primary lamellae and film lamellae, d tail-shaped lamellae adjacent to coarsened primary lamellae, e depleted region adjacent to a quartz inclusion and $\mathbf{f}$ irregularly shaped late albite and microporosity
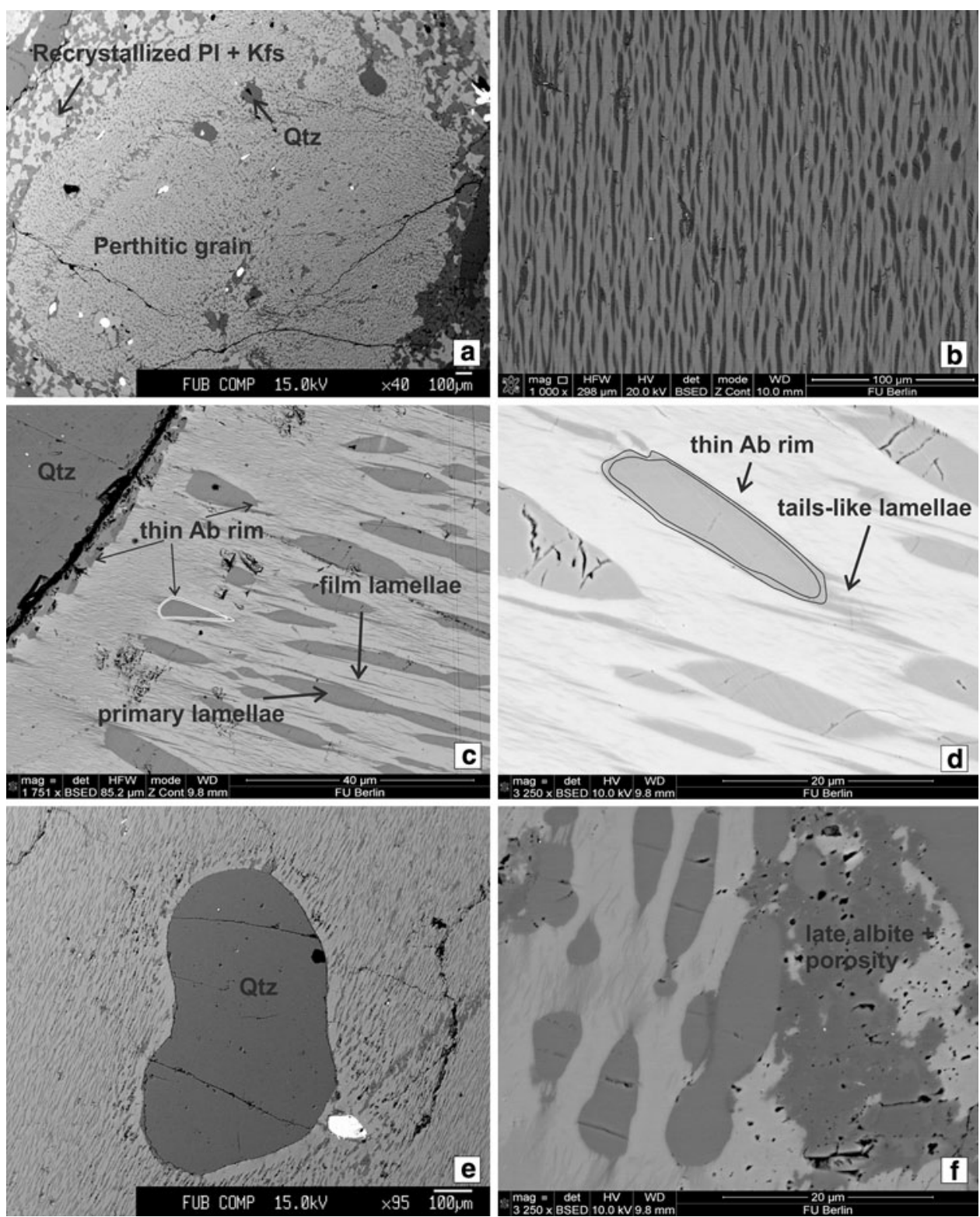

become significantly coarsened and are somewhat less abundant (Fig. 2c, e).

In order to better understand the mechanisms for primary lamellae growth and its coarsening as well as the later film lamellae growth, the size distribution (SD) and shape parameter of the plagioclase precipitates were analysed. The lengths and widths of the plagioclase precipitates were measured and their frequencies plotted. Regarding the prevailing elongated shape and the significant variability in the width of all generations of exsolution lamellae, only the width parameter is presented here as the most representative value for the SD analysis (Fig. 3). In addition, a relation between precipitate dimensions expressed as the Feret diameter, which is the longest diameter in a precipitate, and circularity, defined as $4 \pi^{*}$ area/perimeter ${ }^{\wedge}$, was considered in the following analysis (Fig. 3).

Image analysis was done using the Image $\mathbf{J}$ software. In the first step, the original back-scattered images (BSE) were transferred into a set of binary images. From the binary images, the length of major and minor axes, Feret diameter and circularity for each precipitate were extracted. The SD approach is commonly applied to the size distribution of crystals and represents the number of crystals within specific size intervals (Marsh 1988; Higgins 2000; Eberl et al. 1998, 2002). The frequency distribution of the dimensions of albite-rich precipitates shown in this study is the amount of lamellae within a given size interval normalized to the total amount of lamellae (number of lamellae per interval/total amount of lamellae). The 

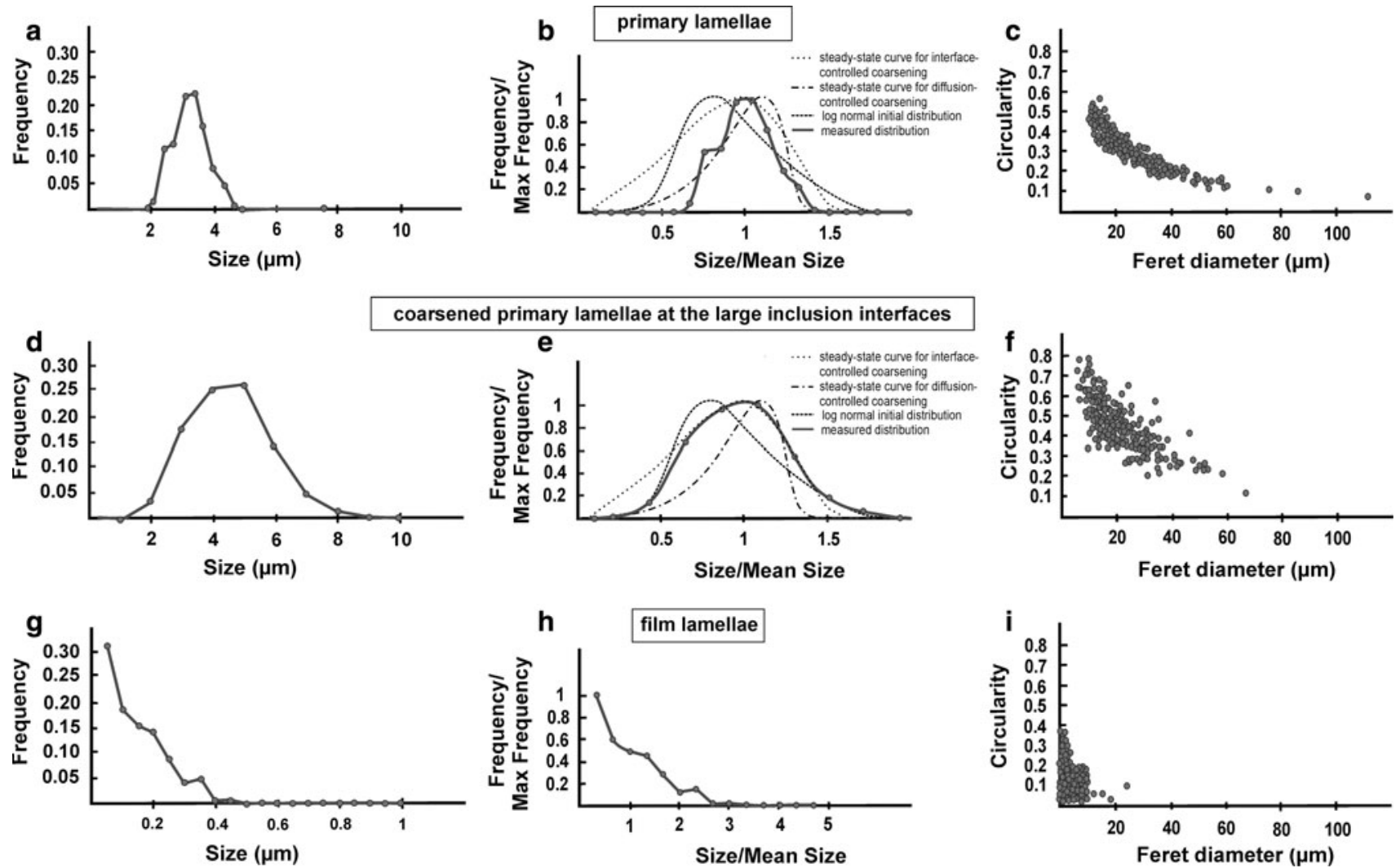

Fig. 3 Size distribution of $\mathbf{a}-\mathbf{c}$ primary lamellae in the homogeneous region of the perthitic feldspar, $\mathbf{d}-\mathbf{f}$ primary lamellae in the coarsened region and $\mathbf{g}-\mathbf{i}$ film lamellae. The first set of diagrams (a, d, g) represents the initial distributions of each precipitate generation (frequency vs. size). The second set of diagrams $(\mathbf{b}, \mathbf{e}, \mathbf{h})$ is

number of size intervals varies with the number of measured particles and the range in lamellae sizes in order to reduce the noise in the measured data. The Feret diameter versus circularity plot provides information on the degree of elongation, whereas the size-distribution diagrams can be used for making comparisons between populations of precipitates for both microstructural settings and for inferences regarding the processes of exsolution and coarsening. For this statistical analysis, a set of more than 200 albite-rich precipitates was considered for each investigated region. Furthermore, the recrystallization mechanism can be determined by plotting size distribution using reduced coordinates (Fig. 3b, e, h; Baronnet 1982, 1984; Eberl et al. 1998; Weinbruch et al. 2006). In order to compare the measured size distributions with the predictions of theoretical models related to normal or lognormal as the most common initial SDs in natural systems and steady-state SDs according to LSW theory (Lifshitz and Slyozov 1961; Wagner 1961), the reduced plots (steadystate distribution) with normalized size (size/mean size) versus normalized frequency (frequency/maximum frequency) were constructed (Fig. 3b, e, h). normalized in order to compare the measured data with theoretical curves for log-normal initial distribution and steady-state curve after Eberl et al. (1998). The third set of diagrams (c, f, i) characterizes the shape of the precipitates

\section{Primary exsolution lamellae in the homogeneous region}

The size-distribution diagrams of the first generation of plagioclase precipitates show Gaussian SDs (Fig. 3a, b). The width distribution of primary exsolution precipitates is narrower than the length distribution. The length distribution ranges from 10 to $65 \mu \mathrm{m}$ with a mean of $27 \mu \mathrm{m}$, whereas the width of the precipitates ranges between 2 and $4 \mu \mathrm{m}$ with a mean of $3 \mu \mathrm{m}$ (Fig. 3a). In the Feret diameter versus circularity plot a well-defined negative correlation between precipitate size and circularity is seen (Fig. 3c), that is, smaller grains tend to be more circular than large grains. A similar relation was reported from alkali feldspar megacrysts with perthitic microstructure by Abart et al. (2009b).

\section{Primary exsolution lamellae in the coarsened region}

The statistical analysis of primary exsolutions from the coarsened regions shows clear Gaussian SDs (Fig. 3d, e). These precipitates are, however, more circular than the primary precipitates from the homogeneous region. The length distribution, though not significantly different from 
the homogeneous region case, is shorter and ranges from 10 to $40 \mu \mathrm{m}$, with a mean of $23 \mu \mathrm{m}$, while the width of the precipitates ranges from 2 to $7 \mu \mathrm{m}$ with a mean of $4.7 \mu \mathrm{m}$ (Fig. 3d). The Feret diameter versus circularity plot shows less pronounced negative correlation between precipitate size and circularity as compared to the precipitates from the homogeneous region. In summary, in the coarsened regions, the albite-rich precipitates are somewhat shorter, significantly wider and, as a consequence, more circular than the precipitates in the homogeneous region (Fig. 3f).

\section{Film lamellae}

The size-distribution diagrams for the film lamellae show different maxima compared to the primary precipitates (Fig. 3g, h). The SD for film lamellae is at the maximum frequency for the smallest lamella size, and then, it monotonically decreases with size. The precipitate length ranges from 1 to $10 \mu \mathrm{m}$ with a mean of $2 \mu \mathrm{m}$, and the width is variable in the range of several 10's of $\mathrm{nm}$. The film lamellae are highly elongated, which is also evident from the Feret diameter versus circularity plot with welldefined negative correlation between precipitate size and circularity (Fig. 3i).

\section{Chemical variations}

The integrated composition of the large perthitic feldspars varies between $\mathrm{Or}_{59} \mathrm{Ab}_{36} \mathrm{An}_{5}$ in the homogeneous regions to the compositions of about $\mathrm{Or}_{63} \mathrm{Ab}_{33} \mathrm{An}_{4}$ near the quartz or kyanite inclusions. The integrated composition of the orthoclase-rich host with film lamellae representative of the stage after the formation of the primary lamellae corresponds to $\mathrm{Or}_{81} \mathrm{Ab}_{19}$. Recrystallized plagioclase in the immediate vicinity of perthitic grains is chemically homogeneous with a composition that ranges from $\mathrm{An}_{18}$ to $\mathrm{An}_{20}$. Recrystallized K-feldspar contains up to 9-13 mol\% of albite component, whereas the anorthite content is below the detection limit.

For both environments, homogeneous and coarsened region, only primary precipitates could be analysed by point analyses. The film lamellae could not be analysed quantitatively. This is due to the loss of sodium when spot analyses are done with high resolution using the field emission gun EMP and analytical TEM. However, several element maps were performed in order to document chemical patterns and chemical relations between host alkali feldspar and all generations of plagioclase precipitates.

\section{Exsolution lamellae in the homogeneous region}

The primary plagioclase precipitates have the compositions of $\mathrm{Ab}_{67-65} \mathrm{An}_{29-32} \mathrm{Or}_{02-03}$ on average in the lamella cores. In a few cases, the anorthite component reached values up to $45 \mathrm{~mol} \%$ in the core regions (Fig. 4a). Generally, the anorthite content decreases towards the rim of the precipitate, whereas the albite content increases slightly to $\mathrm{Ab}_{80-78} \mathrm{An}_{19-21} \mathrm{Or}_{02}$ on average. The orthoclase content is very low (up to $3 \mathrm{~mol} \%$ Or). The element maps of primary precipitates in the homogeneous region (Fig. 4c) document the quite homogeneous composition. The map also illustrates the chemical differences between the primary precipitates with relatively high anorthite content and the film lamellae, which are essentially pure albite. Interestingly, the film lamellae are absent in the immediate vicinity of the primary precipitates (Fig. 4c).

\section{Exsolution lamellae in the coarsened region}

Similarly to the homogeneous region, the primary plagioclase precipitates from the coarsened regions show subtle compositional variations with $\mathrm{Ab}_{76} \mathrm{An}_{22} \mathrm{Or}_{02}$ in the core and slightly lower anorthite content $\mathrm{Ab}_{80} \mathrm{An}_{18} \mathrm{Or}_{02}$ in the rims (Fig. 4b). Generally, the outer, more albite-rich portions of precipitates are wider in the coarsened regions than in the homogeneous region (Fig. 4b). The element distribution maps also show the differences between the primary precipitates (the most anorthitic), albite-rich film lamellae and slightly oblique albite lamellae (tails), which seem to have a similar composition as the film lamellae (Fig. 4d). The regions around coarse primary precipitates are noticeably depleted in film lamellae (Fig. 4e).

\section{TEM and STEM results}

TEM foils were cut from the coarsened region where all types-primary lamellae, film precipitates and oblique tailshaped precipitates - can be observed. All foils were cut perpendicular to the main alignment of the precipitates. In the coarsened region close to large inclusions, the plagioclase precipitates of the first generation are less abundant than in the homogeneous region and eventually missing. The host is tweed orthoclase (Fig. 5a, b, c).

The core regions of coarse precipitates show albite twinning. The interfaces between primary precipitates and the orthoclase-rich host are incoherent (Fig. 5a, b). They are lined by a 20 - to 50 -nm-wide zone comprised of an ultra-fine-grained albite aggregates (Fig. 5a, b). This zone neither shows coherent contrast to the orthoclase-rich host nor does it show albite twinning. It contains abundant micropores up to $20 \mathrm{~nm}$ in size (Fig. $5 \mathrm{a}, \mathrm{b}$ ).

The film albite lamellae show albite twinning and are coherently intergrown with tweed orthoclase (Fig. 5c). The weak tweed structure suggests that the process of ordering was not fully completed in the orthoclase-rich host, which corresponds to a transitional state between orthoclase and 

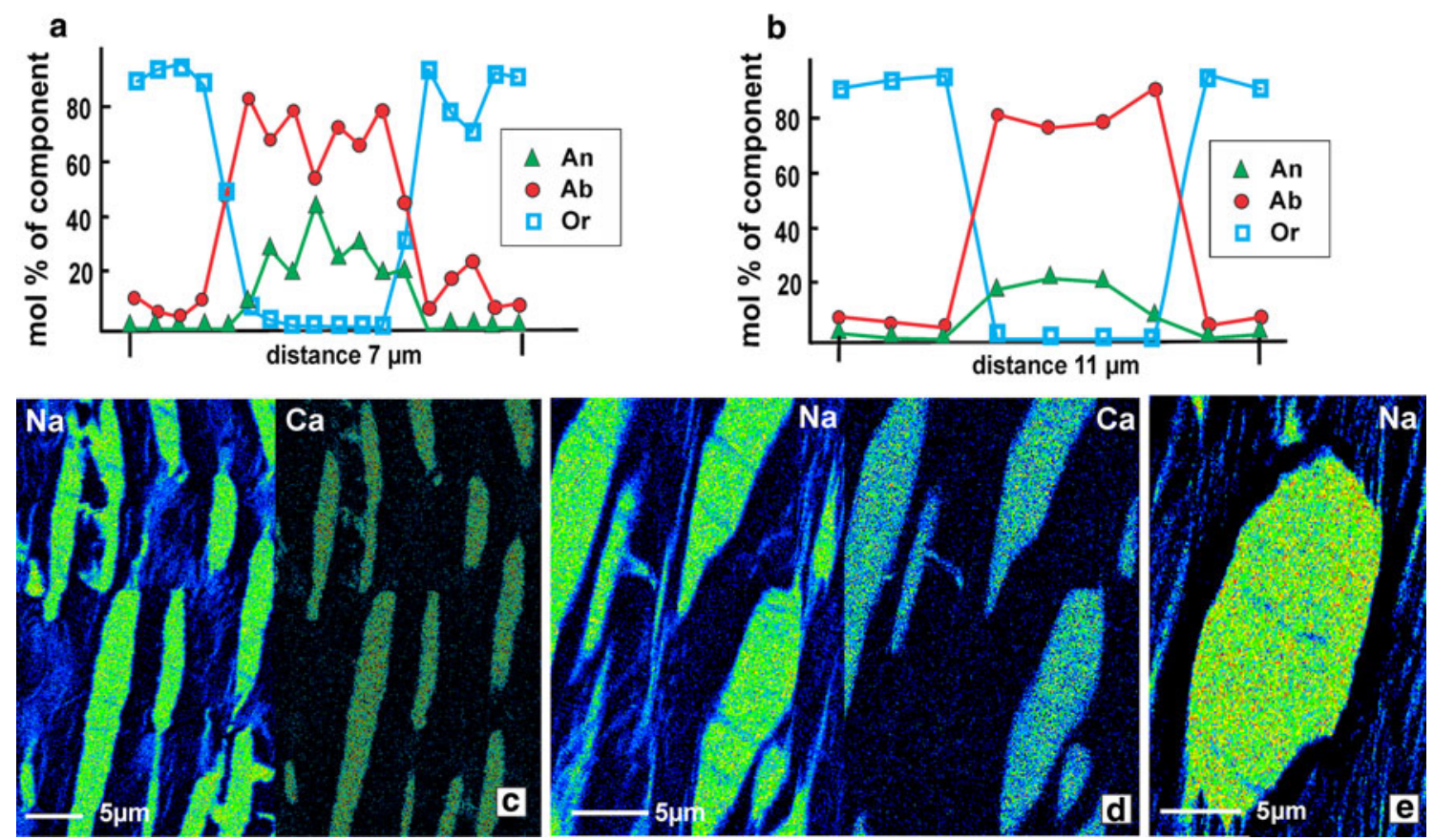

Fig. 4 a Compositional profiles through the primary precipitate in the homogeneous region of the perthitic feldspar. b Compositional profiles through the primary precipitate in the coarsened region. c $\mathrm{Na}_{2} \mathrm{O}$ and $\mathrm{CaO}$ distribution map of detailed part of the

homogeneous region in the perthitic feldspar. d $\mathrm{Na}_{2} \mathrm{O}$ and $\mathrm{CaO}$ distribution maps of coarsened primary lamellae. e Detailed $\mathrm{Na}_{2} \mathrm{O}$ distribution map of coarsened primary lamella

microcline (Fitz Gerald and McLaren 1982; Parsons et al. 2010). In a few cases, the film lamellae are crossed by symmetric linear dislocations resembling "pull-aparts" joining nano-tunnels as described in Fitz Gerald et al. (2006) (Fig. 5c, d). The somewhat younger, tail-shaped, very fine albitic lamellae have still (semi) coherent character with few dislocations (Fig. 5e), whereas the very late diffuse tails are semi-coherent in regions where linear features are absent (Fig. 5f).

\section{Discussion}

Evolution of exsolution lamellae

We discern seven stages in the evolution of the perthitic microstructure (Fig. 6). Numerous works already documented that the felsic granulites from the Blanský les granulite experienced peak pressures around 16-18 kbars (Franěk et al. 2011; Tajčmanová et al. 2011). In order to calculate the peak temperature, two feldspar thermometry based on the thermodynamic model of Benisek et al. (2010) was used. The peak temperature was estimated from an integrated composition of the perthitic grain at $900-950{ }^{\circ} \mathrm{C}$ and the relations are portrayed on the ternary An-Ab-Or diagram in Fig. 6. The $T-X$ diagram (Fig. 6) refers to the An-free system and hence is not valid for a quantitative representation of the interval from peak metamorphic conditions to the formation of the first generation of An-bearing precipitates. It has been shown in Lee and Parsons (1997) that $1 \mathrm{~mol} \%$ of anorthite may shift the strain-free solvus over $100{ }^{\circ} \mathrm{C}$ towards higher $\mathrm{T}$ as compared to the An-free system. The An-bearing system is therefore illustrated based on the assumption that the coherent solvus for the ternary system approximately corresponds to the strain-free solvus for the binary system that lies approximately in the middle between peak temperature conditions and coherent binary solvus. The primary precipitates formed at around $850{ }^{\circ} \mathrm{C}$ during the high-pressure stage (16-18 kbar) when the integrated composition of the perthitic grain crossed the ternary coherent solvus (stage II. in Fig. 7). The anorthite component is strongly fractionated into the primary precipitates, leaving behind an essentially anorthite-free orthoclase-rich host. This is why the binary $T-X$ diagram can be used for portraying the subsequent evolution of the perthite during cooling. Primary exsolution lamellae was followed by primary coarsening of the plagioclase precipitates (stage III. in Fig. 7), which took place between 850 and $700{ }^{\circ} \mathrm{C}$ continuously following the coherent ternary solvus. More significant coarsening of the primary precipitate took place around the large inclusions of quartz, kyanite and garnet and at the rims of the perthitic grains (stage IV. in Fig. 7). The recrystallized plagioclase precipitates at the rims of the large perthitic grains still 


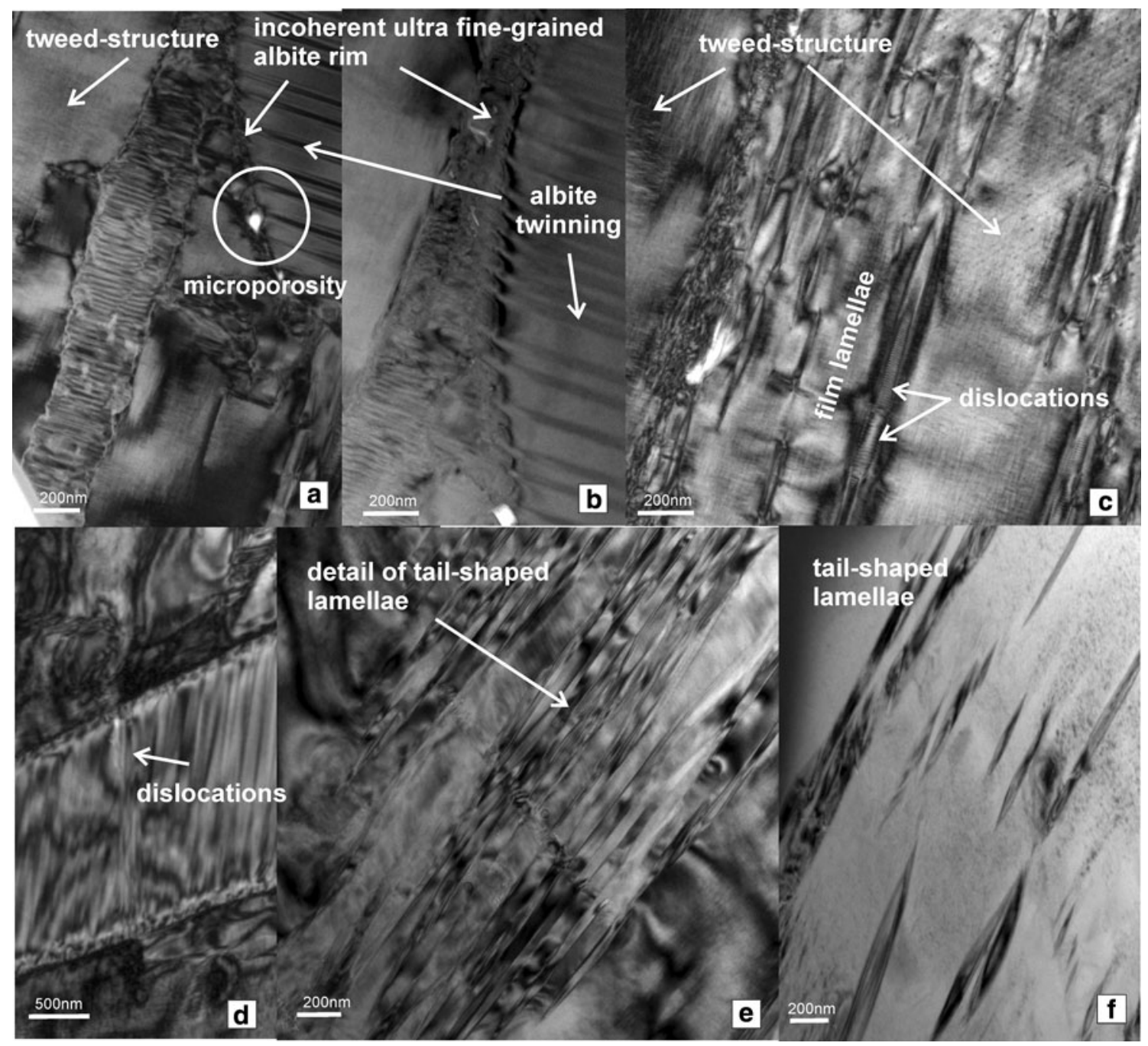

Fig. 5 TEM bright field micrographs of observed precipitates in the perthitic grain. a, b The incoherent interface between coarsened primary lamella and orthoclase-rich host with tweed structure.

have an elevated anorthite content (18-20 mol\% An), indicating that this coarsening must have occurred before pervasive deuteric alteration and albitization still at high temperatures (stage VII. in Fig. 7). This observation is in agreement with the work of Franěk et al. (2011) where the recystallized fabric is inferred to have formed at $800{ }^{\circ} \mathrm{C}$ and $10 \mathrm{kbar}$. During coarsening, the precipitates lost their coherency and were no longer constrained crystallographically to any shape and shape preferred orientation confinement by the host grain lattice. The second generation of albite-rich precipitates was formed at around $570{ }^{\circ} \mathrm{C}$ when the integrated orthoclase-rich host composition $\left(\mathrm{Or}_{81} \mathrm{Ab}_{19}\right)$ crossed the coherent binary solvus (stage V. in Fig. 7). The exsolution of albite film lamellae persisted continuously and tail-shaped lamellae (stage VI. in Fig. 7) were finally formed. The oblique tail-shaped partly diffuse lamellae could lose partly their coherency during the late stages of c, d Film lamellae coherently intergrown with tweed orthoclase. In some parts, tiny dislocations were observed. e, $\mathbf{f}$ Tail-shaped ultra-fine semi-coherent lamellae

cooling connected with a more pervasive fluid influx. The irregularly shaped pure albite precipitates were formed at a late stage of the petrogenetic history probably related to fluid infiltration and associated albitization at around $400{ }^{\circ} \mathrm{C}$ (stage VII. in Fig. 7).

Mechanism for lamellae exsolution and coarsening

The purpose of the SD analysis presented here is to identify the exsolution mechanism for primary and film precipitates as well as the coarsening mechanism of the precipitates of the first generation. It is assumed that the SDs for both possible exsolution mechanism-spinodal decomposition and nucleation and growth-differ at the early stages of the exsolution process. However, the mechanisms controlling microstructure evolution in perthitic feldspars from slowly cooled rocks are difficult to characterize because the original 
Fig. 6 Seven stages of the perthite microstructure evolution. Solvus isotherms calculated using the model of Benisek et al. (2010). The strain-free solvus for the $\mathrm{Ab}-\mathrm{Or}$ binary system is calculated using the Fuhrman and Lindsley (1988) feldspar model calibration

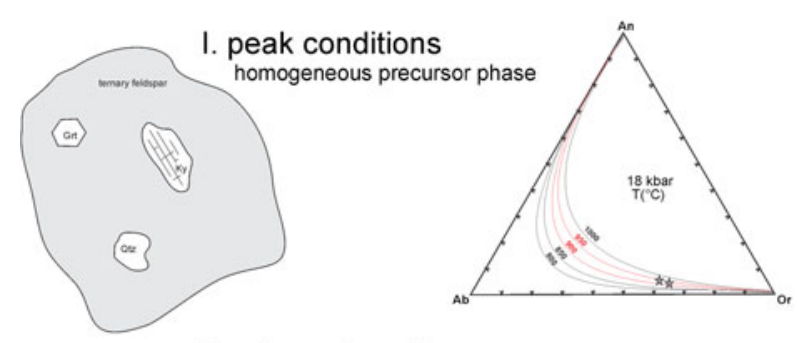

II. primary lamellae

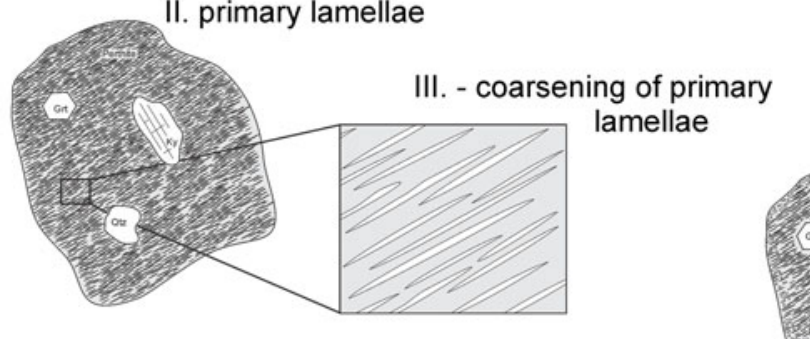

V. film lamellae formation
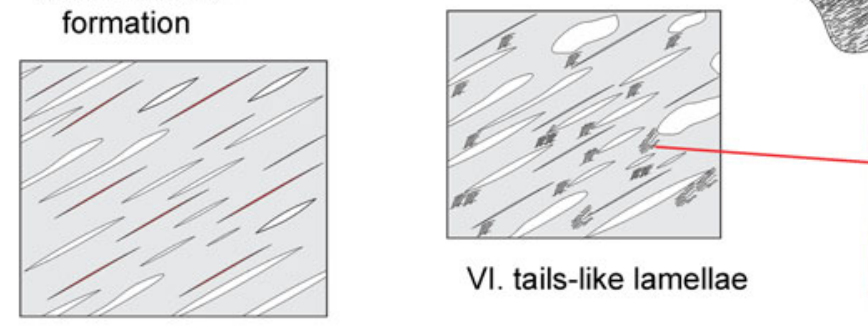

VI. tails-like lamellae

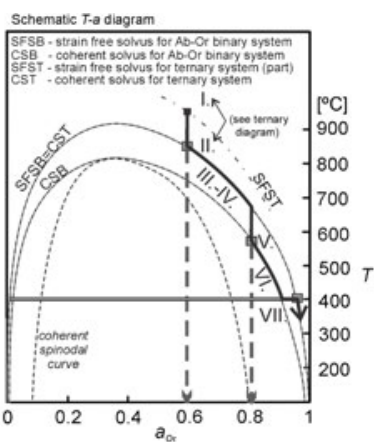

IV. preferential coarsening at the inclusion interfaces and rims of large grains

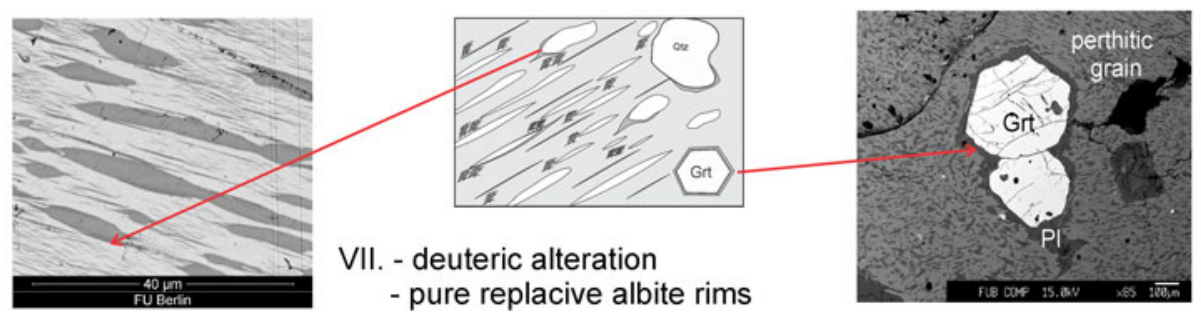

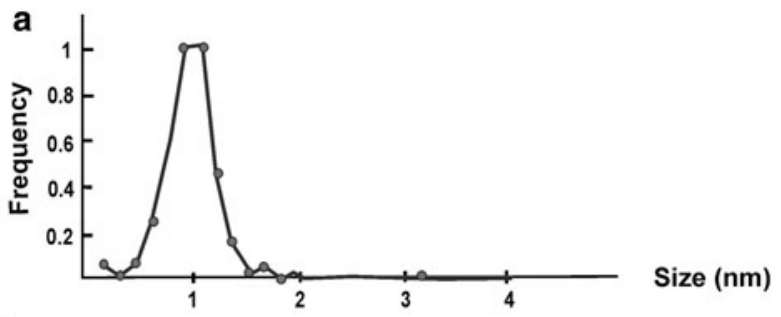
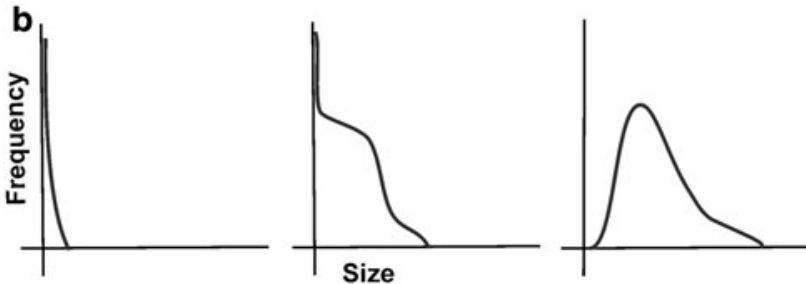

Fig. 7 Size distributions of initial stages of a spinodal decomposition compiled from Neusser (personal communication), Parsons and Brown (1984) and Nord and McCallister (1979) and b Time evolution of nucleation and growth with time after Teran et al. (2010) microstructure and thus the original SD has been, partly or completely, removed during subsequent coarsening.

Coarsening of the particles is driven by a reduction in total interfacial energy, which results in capillary forces that control the morphological change (for details, see e.g. Balluffi et al. 2005). During the process of reduction in interfacial energy, larger grains grow at the expanse of smaller ones (i.e. Ostwald ripening; Ostwald 1900). Depending on the relative rates of material diffusion through the matrix and material absorption at the precipitate-host interfaces, the coarsening can be either diffusion or interface reaction controlled leading to different grainsize distributions (Lifshitz and Slyozov 1961; Wagner 1961; the so-called LSW theory). However, in the classical LSW theory, diffusion-controlled coarsening accounts only for spherical particles (liquid or solid) dispersed in a liquid phase. The theory does not consider the volume fraction, although the diffusion geometry must be strongly affected 
by adjacent precipitates. In many cases of solid-solid transformations, the precipitates are not spherical and coherency stresses as well as the volume fraction can significantly influence the coarsening (Ardell 1972; Ardell and Ozolins 2005; the so-called MLSW theory). If the volume fraction is taken into account following the work of Ardell (1972), the theoretical size distributions lie between the diffusion-controlled and interface-controlled LSW coarsening. For the present perthitic grains, the volume fraction of plagioclase precipitate is between 0.3 and 0.6 , which makes it impossible to distinguish between diffusion- or interface-controlled coarsening because the theoretical distribution for such a diffusion-controlled coarsening is almost identical to the interface-controlled one. For our analysis, we therefore use both end members (diffusion and interface controlled) from classical LSW theory to define the general range of SDs typical of coarsening (or Ostwald ripening), no matter which controlling mechanism was responsible for the resulting microstructure (Fig. 3b, e).

Indirect proof that Ostwald ripening has taken place is given by a steady-state profile (assuming no change in size with time) that is independent of the ripening time and the initial size distribution (Lifshitz and Slyozov 1961; Wagner 1961). The shape and position of the normalized distribution are indicative of the growth-controlling mechanism (Baronnet 1982, 1984). To compare the measured size distributions with the prediction of theoretical models related to initial lognormal and steady-state SDs, plots of the steady-state distribution with normalized size and frequency were therefore constructed (Fig. 3 b, e).

The observed SD shape for precipitates in the homogeneous region (Fig. 3b) lies between the lognormal-initial distribution (skew towards larger lamellae sizes) and steady-state curve for diffusion-controlled coarsening assuming zero volume fraction (skew towards smaller sizes). A better fit between the observed and theoretical distribution for the interface-controlled or diffusion-controlled coarsening for nonzero-volume fraction was obtained for precipitates in the coarsened region (Fig. 3e), which are significantly rounder compared with the precipitates from the homogeneous region. According to the LSW and MLSW theories (Lifshitz and Slyozov 1961; Wagner 1961; Ardell 1972), the inferred distributions thus in both cases account for a loss of "memory" on the initial exsolution process due to progressive coarsening.

Simulations of microstructure evolution during cooling of alkali feldspar indicate that most of the coarsening occurs in a narrow temperature interval of less than about $30{ }^{\circ} \mathrm{C}$ immediately following primary exsolution (Abart et al. 2009a). Regarding the transitional shape of the distribution for the homogeneous region in the reduced plot (Fig. 3b), the coarsening shifted the SD characteristic of the primary exsolution process towards a SD corresponding to a steady-state distribution as is attained during capillary force-driven coarsening. It has, however, not completely erased the original SD so that some "memory" of the mechanisms underlying primary exsolution was retained. Ostwald ripening is also indicated by the haloes around the recrystallized plagioclase precipitates where the albite content of the host grain is depleted (Figs. 2c-f; 4c-e).

The SD for film lamellae shows a remarkably different initial distribution with respect to primary lamellae (Fig. 3g, h). The film lamellae did not undergo such a pervasive coarsening as the primary precipitates did, and the corresponding SD more reflects the mechanism underling their formation. The results of the SDs for the natural observation in our samples were compared with the studies on representative initial stages of spinodal decomposition and nucleation and growth available from the literature (Fig. 7). The spinodal decomposition distributions taken from exsolution experiments of Neusser (personal communication), Nord and McCallister (1979), Parsons and Brown (1984) and Weinbruch et al. (2003, 2006) with lense-shaped precipitates on the order of tens to about one hundred nanometres were compiled and showed a classical Gaussian distribution already for the initial stages (Fig. 7a). On the other hand, a non-Gaussian distribution for nucleation and growth from the work of Teran et al. (2010) resembles the distribution of the film precipitates described here (Fig. 7b). The information on initial distribution for primary precipitates in our samples was already partly erased, which prevents us from defining an exsolution mechanism based on the SD analysis. However, the initial Gaussian shape of the spinodal decomposition distribution based on the published data clearly contrasts to the distribution typical of nucleation and growth (Fig. 7). Furthermore, although the position of the ternary solvus and ternary spinodal curve is not known accurately, it is expected that the anorthite content enlarges the spinodal region. It is therefore hypothesized that the nearly intermediate integrated composition of the studied perthitic grains points to spinodal decomposition during primary precipitate formation. In contrast, the described SD for film precipitates seems not to be affected by ongoing coarsening, and the distribution is identical with the published SD on initial stages of exsolution process by the nucleation and growth mechanism (Fig. 7).

Fluid pathways

The granulites from the Blanský les granulites were interpreted as "dry" rocks (Fiala et al. 1987; Jakeš 1997; Kotková and Harley 1999; Finger et al. 2003; Janoušek et al. 2004, 2006; Janoušek and Holub 2007). However, the fact that the coarsening and recrystallization of the primary 
precipitates were enhanced in regions in the vicinity of the large inclusion and at the margins of the perthitic grains suggests that the coarsening was mediated by a fluid or melt phase already at high temperatures. Such a phase penetrated along the inner and outer surfaces of the perthitic grain, where it is very likely that the inner surfaces, that is, the interfaces between the perthitic grain and large inclusions of quartz, kyanite and garnet were interconnected with the rock matrix through imperfections in the perthitic grain such as fractures or cleavage planes which served as preferred fluid passageways. The preferential development of imperfections at the phase boundaries may be related to the differences in thermal expansion, where coefficients of thermal expansion of kyanite and quartz are approximately 30 and $100 \%$ larger than that of alkali feldspar, respectively. It is important to mention that coarsening might have also been influenced by "strength" of a material to a particular degree. In the Bingham-like viscous model, material strength (in this case alkali feldspar) is reduced at regions with higher stress (Mazzini et al. 2009). Such regions may, in this work, correspond to the interfaces of large inclusions inside the large perthitic grains and also to margins of these grains that are prone to misfit, and thus, the surface stress might be higher than in the homogenous part of the grain. Such a reduction in material strength may elevate the reaction rate or coarsening even without the contribution of a fluid phase (Schmid et al. 2009). However, as these regions are also prone to enhance a density of defects or imperfections which allow for access of fluids, it is believed that the effect of such imperfections would probably outweigh any feedback of induced stress and elastic strain on free energy.

Electron energy loss spectroscopy (EELS) applied to thin foil cuts from "homogeneous" and "coarsened" regions revealed the presence of hydrogen-bearing species along the precipitate-host interfaces, whereas such species were neither detected in the interior of the precipitates nor in the interior of the orthoclase-rich host (Fig. 8). The prepeak in the $\mathrm{O}-\mathrm{K}$ edge spectrum at about $528 \mathrm{eV}$ was attributed to the presence of OH (Wirth 1997). However, the application of EELS analysing hydroxyl-bearing species was questioned by Garvie (2010), who showed pitfalls connected with semi-quantitative measurements of $\mathrm{H}$ in hydrate minerals using EELS. In our analysis, EELS was used in a qualitative sense, that is, the distribution of hydroxyl-bearing species was analysed within one mineral or within the two-phase perthitic assemblage following the work of Klimenkov et al. (2008) and Abart et al. (2009a). From EELS data, we infer that the interfaces between the plagioclase precipitates and the orthoclase-rich host served also as passageways for the infiltration of fluid/melt into the perthitic grain.
Once melt entered the interior of the perthitic feldspar through imperfections at high temperatures (stages III and IV, Fig. 6), it facilitated coarsening. Apparently, the fluid/ melt was in chemical equilibrium with the alkali feldspar, because it did not cause any compositional changes. It seems to only have accelerated the kinetics of coarsening. The presence of fluid/melt affects the rates of grain coarsening and recrystallization as the activation energy for the development and migration of dislocations is lowered. The fluid/melt phase thus facilitates the formation of imperfections at the interfaces between precipitate and host successively reducing the degree of coherency of these phase boundaries (Brown and Willaime 1974; Brown and Parsons 1993). The coarsening requires chemical mass transfer either along the host-precipitate phase boundaries and/or through the volume of the orthoclase-rich host. The most likely mechanism of accelerating this kinetics is by weakening bonds by hydroxylation because the coarsening also implies redistribution of $\mathrm{Al}-\mathrm{Si}$ as plagioclase precipitates with considerable An-content were involved. The fluid/melt therefore allowed for hydroxylation that leads to the weakening of the bonds in the tetrahedral framework. As inferred from the relatively high anorthite content of the recrystallized precipitates, this process occurred at high temperatures, and close to peak pressure-temperature conditions.

In contrast to the coarsening of the primary plagioclase precipitates, the replacive albite, which was observed in
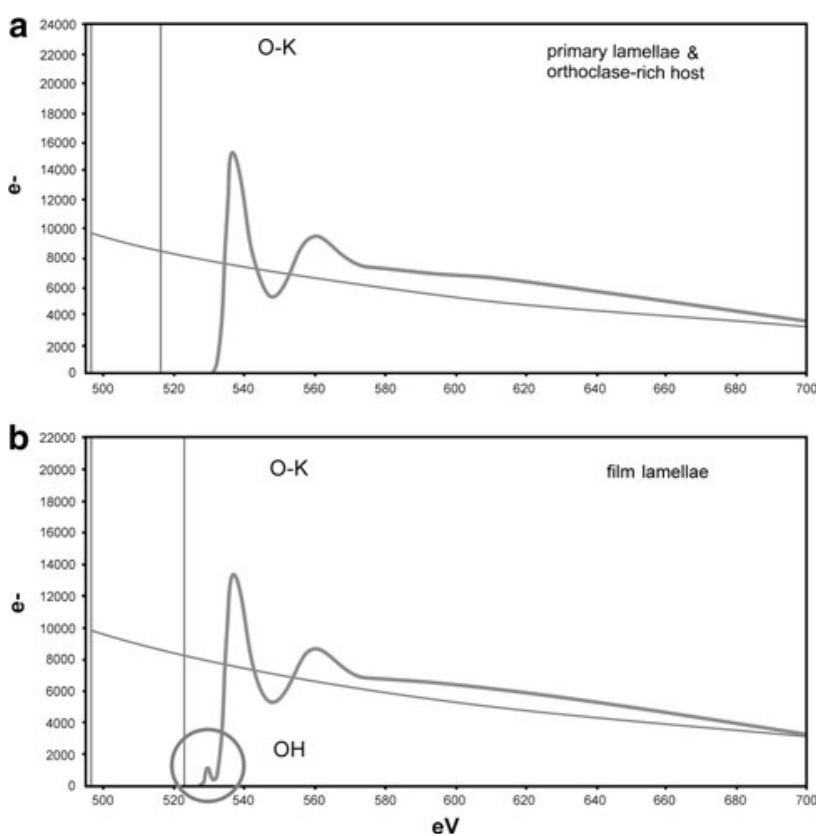

Fig. 8 Electron energy loss spectra (EELS) from a the inner part of primary lamellae and the orthoclase-rich host without the O-K edge pre-peak at about $528 \mathrm{eV}$ and $\mathbf{b}$ precipitates-host interfaces with the O-K edge pre-peak 

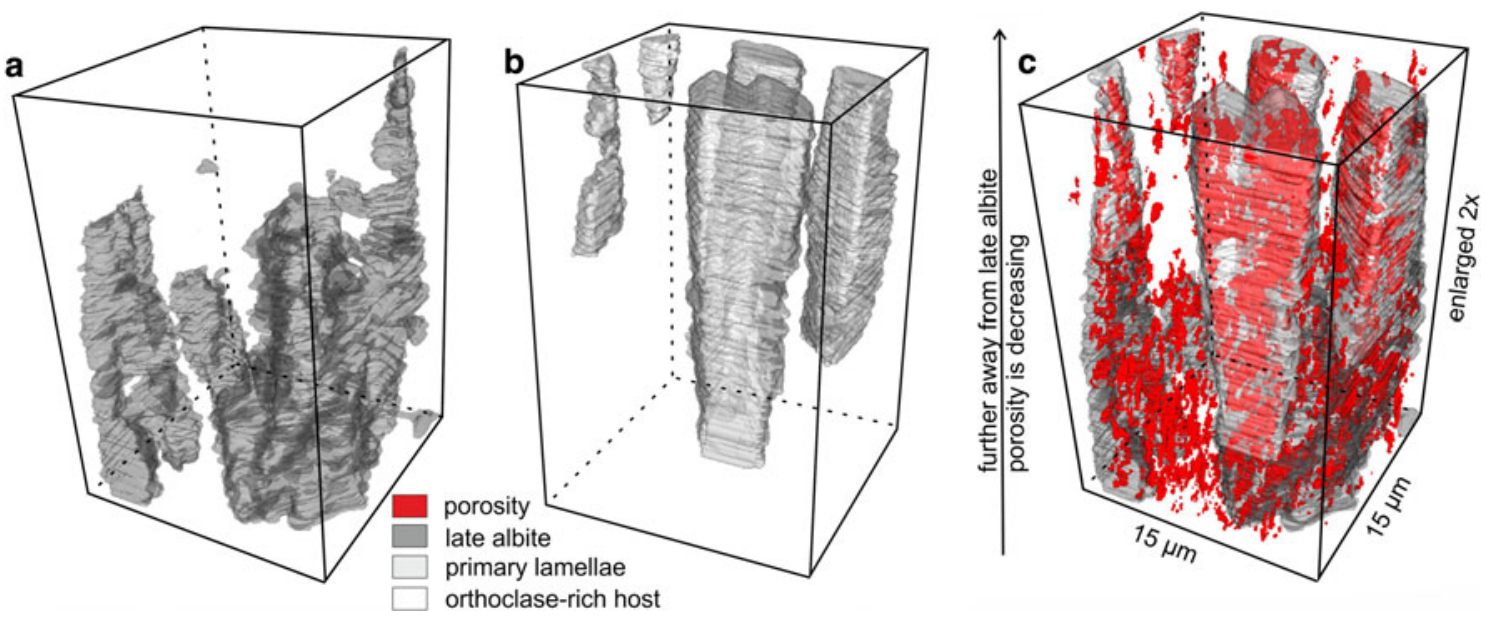

Fig. 9 The three-dimensional distribution of porosity obtained by FIB serial sectioning (200 slices of $0.1 \mu \mathrm{m}$ thickness each) from an albitized region within the orthoclase-rich host (bottom) towards late albite-free region with primary lamellae (top). a Late albite distribution. b Primary exsolution lamellae distribution. c Distribution of porosity with respect to late albite, primary exsolution lamellae and orthoclase-rich host

The weak 3D interconnectivity of reaction-induced porosity in experimental material on a similar scale has been recently described by Norberg et al. (2011). In the present samples of high-grade "dry" rocks, the 3D interconnectivity (Fig. 9) is even weaker than in the material produced by experimental albitization (Norberg et al. 2011). The pores are most abundant in the regions with irregular albite "spots" (Fig. 9a, c; dark grey, lower part of the box), which causes the turbidity in the host alkali feldspar (white part of the box in Fig. 9). Somewhat less abundant pores were also observed in the inner parts of coarsened primary lamellae (light grey; Fig. 9b, c) in the "coarsened" region. On the contrary, only weak microporosity was observed in the pure orthoclase-rich host far away from the replacive albite (upper white part of the box; Fig. 9c). Part of the porosity might be associated with reduction in the molar volume changes, and such reductions, however, cannot be very significant, if a closed bulk chemical system is assumed. Regarding the amount of pores present in the perthitic feldspar, it is believed that part of the material must have been removed during the dissolution-reprecipitation process (Walker et al. 1995; Putnis 2002, 2009).

The replacive irregular pure albite associated with albitization was obviously mediated by a significantly higher amount of fluids compared with the initial stages of alteration. However, regarding the at least partly preserved perthitic structure with primary lamellae and the restriction of replacive albite only to the vicinity of large inclusions, the albitization was not massive. If the rock had undergone more significant albitization, all information on SDs would have been completely removed. 
Acknowledgments We are grateful to J. Franěk for providing such interesting samples. The Alexander von Humboldt Foundation is thanked for its financial support of L.T. during her research stay at the Free University of Berlin. SEM-FIB work at the University of Vienna was funded by the Austrian Science Fund (FWF) project number I471-N19. I. Parsons and one anonymous reviewer are thanked for their very constructive reviews and T.L. Grove for his careful editorial work.

\section{References}

Abart R, Petrishcheva E, Wirth R, Rhede D (2009a) Exsolution by spinodal decomposition II: perthite formation during slow cooling of anatexites from Ngoronghoro, Tanzania. Am J Sci 309:450-475

Abart R, Petrishcheva E, Kässner S, Milke R (2009b) Perthite microstructure in magmatic alkali feldspar with oscillatory zoning; Weinsberg Granite, Upper Austria. Miner Petrol 97:251-263

Ardell AJ (1972) The effect of volume fraction on particle coarsening: theoretical considerations. Acta Metall 20:66-71

Ardell AJ, Ozolins V (2005) Trans-interface diffusion-controlled coarsening. Nat Mater 4:309-316

Balluffi RW, Allen SM, Carter WC (2005) Kinetics of materials ISBN: 9780471246893 Baker and Taylor (USA)

Baronnet A (1982) Ostwald ripening in solution. The case of calcite and mica. Estudios G eologicos (Madrid) 38:185-198

Baronnet A (1984) Growth kinetics ofthe silicates. A review of basic concepts. Fortschr Mineral 62:187-232

Benisek A, Dachs E, Kroll H (2010) A ternary feldspar-mixing model based on calorimetric data: development and application. Contrib Mineral Petrol 160:327-337

Brown WL, Parsons I (1984a) Exsolution and coarsening mechanisms and kinetics in an ordered cryptoperthite series. Contrib Mineral Petrol 86:3-18

Brown WL, Parsons I (1984b) The nature of potassium feldspar, exsolution microtextures and development of dislocations as a function of composition in perthitic alkali feldspars. Contrib Mineral Petrol 86:335-341

Brown WL, Parsons I (1988) Zoned ternary feldspars in the Klokken intrusion: exsolution textures and mechanisms. Contrib Mineral Petrol 98:444-454

Brown WL, Parsons I (1989) Alkali feldspars: ordering rates, phase transformations and behaviour diagrams for igneous rocks. Mineral Mag 53:25-42

Brown WL, Parsons I (1993) Storage and release of elastic strain energy the driving force for low temperature reactivity and alteration of alkali feldspars. In: Boland JN, Fitz Gerald JD (eds) Defects and processes in the solid state geoscience applications. The McLaren volume (Developments in petrology 14). Elsevier, Amsterdam, pp 267-290

Brown WL, Willaime C (1974) An explanation of exsolution orientations and residual strain in cryptoperthites. In: MacKenzie WS, Zussman J (eds) The feldspars. Manchester University Press, Manchester, pp 440-459

Cahn JW (1968) Spinodal decomposition. Trans Metall Soc AIME 242:166-180

Cahn JW, Hilliard JE (1958) Free energy of a non-uniform system. I. Interfacial free energy. J Chem Phys 28:258-267

Cahn JW, Hilliard JE (1959) Free energy of a non-uniform system. III. Nucleation in a two-component incompressible Guid. J Chem Phys 31:688-699

Eberl DD, Drits VA, Srodon J (1998) Deducing growth mechanisms for minerals from the shapes of crystal size distributions. Am J Sci 298:499-533
Eberl DD, Kile DE, Drits VA (2002) On geological interpretations of crystal size distributions: constant vs. proportionate growth. Am Mineral 87:1235-1241

Evangelakakis C, Kroll H, Voll G, Wenk HR, Meisheng H, Koepcke J (1993) Low-temperature coherent exsolution in alkali feldspars from high-grade metamorphic rocks of Sri Lanka. Contrib Mineral Petrol 114:519-532

Fiala J, Matějovská O, Vaňková V (1987) Moldanubian granulites: source material and petrogenetic considerations. Neues Jahrb Mineral Abh 157:133-165

Finger F, Cooke R, Janoušek V, Konzett J, Pin C, Roberts MP, Tropper P (2003) Petrogenesis of the south Bohemian granulites: the importance of crystal-melt relationships. J Czech Geol Soc 48:44-45

Fitz Gerald FD, McLaren AC (1982) The microstructures of microcline from some granitic rocks and pegmatites. Contrib Mineral Petrol 80:219-229

Fitz Gerald JD, Parsons I, Cayzer N (2006) Nanotunnels and pullaparts: defects of exsolution lamellae in alkali feldspars. Am Mineral 91:772-783

Franěk J, Schulman K, Lexa O (2006) Kinematic and rheological model of exhumation of high pressure granulites in the Variscan orogenic root: example of the Blanský les granulite, Bohemian Massif, Czech Republic. Mineral Petrol 86:253-276

Franěk J, Schulmann K, Lexa O, Ulrich S, Štípská P, Haloda J, Týcová P (2011) Origin of felsic granulite microstructure by heterogeneous decomposition of alkali feldspar and extreme weakening of orogenic lower crust during the Variscan orogeny. J Metamorph Geol 29:103-130

Fuhrman ML, Lindsley DH (1988) Ternary-feldspar modeling and thermometry. Am Mineral 73:201-215

Garvie LAJ (2010) Can electron energy-loss spectroscopy (EELS) be used to quantify hydrogen in minerals from the O K edge? Am Mineral 95:92-97

Hartmann K, Wirth R, Markl G (2008) P-T-X-controlled element transport through granulite-facies ternary feldspar from Lofoten, Norway. Contrib Mineral Petrol 156:359-375

Higgins M (2000) Measurement of crystal size distributions. Am Mineral 85:1105-1116

Jakeš P (1997) Melting in high-P region-case of Bohemian granulites. Acta Univ Carol Geol 41:113-125

Janoušek V, Holub FV (2007) The causal link between HP-HT metamorphism and ultrapotassic magmatism in collisional orogens: case study from the Moldanubian Zone of the Bohemian Massif. Proc Geol Assoc 118:75-86

Janoušek V, Finger F, Roberts M, Frýda J, Pin C, Dolejš D (2004) Deciphering the petrogenesis of deeply buried granites: wholerock geochemical constraints on the origin of largely undepleted felsic granulites from the Moldanubian Zone of the Bohemian Massif. Trans R Soc Edinb Earth Sci 95:141-159

Janoušek V, Gerdes A, Vrána S, Finger F, Erban V, Friedel G, Braithwaite CJ (2006) Low-pressure granulites of the Lisov Massif, Southern Bohemia: visean metamorphism of Late Devonian plutonic arc rocks. J Petrol 47:705-744

Klimenkov M, Möslang A, Lindau R (2008) EELS analysis of complex precipitates in PM 2000 steel. Eur Phys J Appl Phys 42:293-303

Kotková J, Harley SL (1999) Formation and evolution of highpressure leucogranulites: experimental constraints and unresolved issues. Phys Chem Earth Part A: Solid Earth Geodesy 24:299-304

Kretz R (1983) Symbols for rock forming minerals. Am Mineral 68:277-279

Lee MR, Parsons I (1997) Dislocation formation and albitization in alkali feldspars from the Shap granite. Am Mineral 82:557-570

Lifshitz IM, Slyozov VV (1961) The kinetics of precipitation from supersaturated solid solutions. J Phys Chem Solids 19:35-50 
Marsh BD (1988) Crystal Size distribution (CSD) in rocks and kinetics and dynamics of crystallization. 1. Theory. Contrib Mineral Petrol 99:277-291

Mazzini A, Nermoen A, Krotkiewski M, Podladchikov Y, Planke S, Svensen H (2009) Strike-slip faulting as a trigger mechanism for overpressure release through piercement structures. Implications for the Lusi mud volcano, Indonesia. Marine Petrol Geol 26:1751-1765

Nauman EB, He DQ (2001) Nonlinear diffusion and phase separation. Chem Eng Sci 56:1999-2018

Norberg N, Neusser G, Wirth R, Harlov D (2011) Microstructural evolution during experimental albitization of K-rich alkali feldspar. Contrib Mineral Petrol 162:531-546

Nord GL, McCallister RH (1979) Kinetics and mechanism of decomposition in WozsEnrrFsaac linopyroxene. Geologic Society of America Abstracts with Programs 11:488

Ostwald W (1900) Ueber die vermeintliche Isomerie des roten und gelben Quecksilberoxyds und die Oberflaechenspannung fester Koerper. Z Phys Chem 34:495-503

Owen DC, McConnell JDC (1974) Spinodal unmixing in alkali feldspar. In MacKenzie WS, Zussman J (eds) The Feldspars, Proceedings of a NATO Advanced Study Institute, Manchester University Press, Manchester pp 424-439

Parsons I, Brown WL (1983) A TEM and microprobe study of a twoperthite alkali gabbro: implications for the ternary feldspar system. Contrib Mineral Petrol 81:1-12

Parsons I, Brown WL (1984) Feldspars and the thermal history of igneous rocks. In: Brown WL (ed) Feldspars and feldspathoids: structure, properties and occurrences. NATO ASI Series C, Reidel Publishing Co, Dordrecht, pp 317-371

Parsons I, Lee M (2009) Mutual replacement reactions in alkali feldspars I: microtextures and mechanisms. Contrib Mineral Petrol 157:641-661

Parsons I, Thompson P, Lee MR, Cayzer N (2005) Alkali feldspar microtextures as provenance indicators in siliciclastic rocks and their role in feldspar dissolution during transport and diagenesis. J Sediment Res 75:921-942

Parsons I, Fitz Gerald JD, Lee JKW, Ivanic T, Golla-Schindler U (2010) Time-temperature evolution of microtextures and contained fluids in a plutonic alkali feldspar during heating. Contrib Mineral Petrol 160:155-180

Prior DJ, Boyle AP, Brenker F, Cheadle MC, Day A, Lopez G, Peruzzo L, Potts GJ, Reddy S, Spiess R, Timms NE, Trimby P, Wheeler J, Zetterström L (1999) The application of electron backscatter diffraction and orientation contrast imaging in the SEM to textural problems in rocks. Am Mineral 84:1741-1759

Putnis A (2002) Mineral replacement reactions: from macroscopic observations to microscopic mechanisms. Mineral Mag 66:689708

Putnis A (2009) Mineral replacement reactions. Rev Mineral Geochem 70:87-124

Randle V (1992) Microtexture Determination and its Applications. The Institute of Materials, London 174:29

Randle V, Engler O (2000) Introduction to texture analysis: macrotexture, microtexture and orientation mapping. CRC, London

Schmid DW, Abart R, Podladchikov YY, Milke R (2009) Matrix rheology effects on reaction rim growth II: coupled diffusion and creep model. J Metamorph Geol 27:83-91
Schulmann K, Kroener A, Hegner E, Wendt I, Konopásek J, Lexa O, Štípská P (2005) Chronological constraints on the pre-orogenic history, burial and exhumation of deepseated rocks along the eastern margin of Variscan orogen, Bohemian Massif, Czech Republic. Am J Sci 305:407-448

Schulmann K, Lexa O, Štípská P, Racek M, Tajčmanová L, Konopásek J, Edel JB, Peschler A, Lehman J (2008) Vertical extrusion and horizontal channel flow of orogenic lowercrust: key exhumation mechanisms in large hot orogens? J Metamorph Geol 26:273-297

Štípská P, Powell R, White RW, Baldwin JA (2010) Using calculated chemical potential relationships to account for coronas around kyanite: an example from the Bohemian Massif. J Metamorph Geol 28:97-116

Suess FE (1912) Die Moravischen Fenster und ihre Beziehung zum Grundgebirge des Hohen Gesenkes. Akademie der Wissenschaften, Denkschrift Matematisch-Naturwissenschaftliche Klasse 88:541-631

Tajčmanová L, Konopásek J, Schulmann K (2006) Thermal evolution of the orogenic lower crust during exhumation within a thickened Moldanubian root of the Variscan belt of Central Europe. J Metamorph Geol 24:119-134

Tajčmanová L, Soejono I, Konopásek J, Košler J, Kloetzli U (2010) Structural position of high-pressure felsic to intermediate granulites from NE Moldanubian zone (Bohemian Massif). J Geol Soc Lond 167:329-345

Tajčmanová L, Abart R, Neusser G, Rhede D (2011) Growth of decompression plagioclase rims around metastable kyanite from high-pressure felsic granulites (Bohemian Massif). J Metamorph Geol 29:1003-1018

Teran AV, Bill A, Bergmann RB (2010) Time-evolution of grain size distributions in random nucleation and growth crystallization processes. Phys Rev B 81:075319-19

Wagner C (1961) Theorie der Alterung von Niederschlägen durch Umlösen (Ostwald Reifung). Zeitschrift Elektrochemie 65:581591

Walker FDL, Lee MR, Parsons I (1995) Micropores and micropermeable texture in alkali feldspars: geochemical and geophysical implications. Mineral Mag 59:505-534

Weinbruch S, Styrsa V, Mueller WF (2003) Exsolution and coarsening in iron-free clinopyroxene during isothermal annealing. Geochim Cosmochim Acta 67:5071-5082

Weinbruch S, Styrsa V, Dirsch T (2006) The size distribution of exsolution lamellae in iron-free clinopyroxene. Am Mineral 91:551-559

Wirth R (1997) Water in minerals detectable by electron energy-loss spectroscopy EELS. Phys Chem Minerals 24:561-568

Wirth R (2004) Focused ion beam (FIB): a novel technology for advanced application of micro- and nanoanalysis in geosciences and applied mineralogy. Eur J Miner 16:863-876

Wirth R (2009) Focused ion beam (FIB) combined with SEM and TEM: advanced analytical tools for studies of chemical composition, microstructure and crystal structure in geomaterials on a nanometre scale. Chem Geol 261:217-229

Yund RA (1984) Coherent exsolution in the alkali feldspars. In: Hofmann AW, Giletti BJ, Yoder HS Jr, Yund RA (eds) Geochemical transport and kinetics. Carnegie Institution of Washington publication 634:173-183 